\title{
Status of Nordic research on simulation- based learning in healthcare: an integrative review
}

\author{
Sissel Eikeland Huseb $\emptyset^{1,2,3^{*}}$, Minna Silvennoinen ${ }^{4,5}$, Eerika Rosqvist ${ }^{6}$ and Italo Masiello ${ }^{7}$
}

\begin{abstract}
Background: Based on common geography, sociopolitics, epidemiology, and healthcare services, the Nordic countries could benefit from increased collaboration and uniformity in the development of simulation-based learning (SBL). To date, only a limited overview exists on the Nordic research literature on SBL and its progress in healthcare education. Therefore, the aim of this study is to fill that gap and suggest directions for future research.

Methods: An integrative review design was used. A search was conducted for relevant research published during the period spanning from 1966 to June 2016. Thirty-seven studies met the inclusion criteria. All included studies were appraised for quality and were analyzed using thematic analysis.

Results: The Nordic research literature on SBL in healthcare revealed that Finland has published the greatest number of qualitative studies, and only Sweden and Norway have published randomized control trials. The studies included interprofessional or uniprofessional teams of healthcare professionals and students. An assessment of the research design revealed that most studies used a qualitative or a descriptive design. The five themes that emerged from the thematic analysis comprised technical skills, non-technical skills, user experience, educational aspects, and patient safety.

Conclusion: This review has identified the research relating to the progress of SBL in the Nordic countries. Most Nordic research on SBL employs a qualitative or a descriptive design. Shortcomings in simulation research in the Nordic countries include a lack of well-designed randomized control trials or robust evidence that supports simulation as an effective educational method. In addition, there is also a shortage of studies focusing on patient safety, the primary care setting, or a combination of specialized and primary care settings. Suggested directions for future research include strengthening the design and methodology of SBL studies, incorporating a cross-country comparison of studies using simulation in the Nordic countries, and studies combining specialized and primary care settings.
\end{abstract}

Keywords: Integrative review, Nordic countries, Simulation-based learning

\section{Background}

Since the publication of the seminal book "To Err is Human" [1], which identified the need to train professionals in interprofessional teamwork as one of the many approaches to prevent medical errors, the use of SBL in healthcare has increased. SBL is used as a pedagogical method for training teamwork skills and clinical skills.

\footnotetext{
*Correspondence: sissel.i.husebo@uis.no

${ }^{1}$ Faculty of Health Sciences, University of Stavanger, Stavanger, Norway

${ }^{2}$ Department of Surgery, Stavanger University Hospital, Stavanger, Norway

Full list of author information is available at the end of the article
}

SBL has since become an important technique employed to enhance quality of care and patient safety in healthcare [2-8]. Today, SBL is broadly used in several healthcare professions and in clinical practice, including graduate and postgraduate nursing education and nursing practice $[4,5,8-11]$, graduate and postgraduate medical education, and medical practice $[3,12-19]$, health professional practice [11], and interprofessional education [7, 20-22]. In this paper, simulation is defined as "A dynamic process involving the creation of a hypothetical opportunity that incorporates an authentic representation of reality, facilitates active

(c) The Author(s). 2018 Open Access This article is distributed under the terms of the Creative Commons Attribution 4.0 International License (http://creativecommons.org/licenses/by/4.0/), which permits unrestricted use, distribution, and 
(participant) engagement, and integrates the complexities of practical and theoretical learning with opportunity for repetition, feedback, evaluation and reflection" ([23], p., 668).

Parallel to an increased international prevalence in the areas of both research and training, SBL has gained increasing attention in the Nordic countries: Denmark, Finland, Sweden, Iceland, and Norway [24]. These countries have common geography, sociopolitics, epidemiology, and healthcare services. A myriad of simulation activities across the Nordic countries resulted in the establishment of the "Nordic Network for Simulation-based Learning", following the Swedish Society for Clinical Training and Medical Simulation (KlinSim.se) conference in 2016. The purpose of this Nordic network is to promote and advance simulation research in healthcare and to facilitate collaboration in research efforts and in the implementation of research-based recommendations among the Nordic countries. Scant attention has been paid in the research literature to the progress of SBL in the Nordic countries, and to date, only a limited overview exists. It has been noted in the NordForsk strategy (an organization within the Nordic Council of Ministers that finances Nordic collaboration within research) that these countries would benefit from increased collaboration and uniformity in the development of SBL [25]. In this context, the Nordic network sought to explore the status of SBL in the Nordic countries by performing an extensive, collective review of the existing Nordic simulation literature.

Therefore, the aim of the current literature review is to provide a general overview of the Nordic research literature on SBL in healthcare education and to suggest directions for future research.

The review questions addressed were as follows:

1. What is the current status of research on simulation-based learning in healthcare education?

2. Which professions have been addressed in the research on simulation-based learning?

3. Which research designs have been adopted in the research on simulation-based learning?

4. Which areas of simulation-based learning in healthcare education can be identified in the Nordic research literature?

\section{Methods}

The integrative review was conducted following Evans' outline ([26], p., 146). This involved a strategy comprising several stages that included a review focus, search strategy, selection criteria, critical appraisal, data collection, data synthesis, results, discussion, and analysis. This approach allowed for the inclusion of diverse methodologies in order to more fully understand the phenomenon of concern $[26,27]$. To minimize bias in the review process, a review protocol with a systematic search process was developed, in accordance with Lefebvre et al. [28].
The Participants, Intervention, Comparison, and Outcomes (PICO) framework [29] was used to guide the format of the search process (see Table 1).

\section{Search methods}

The first author (SEH) searched five online bibliographic databases: Academic Search Premier (ASP), CINAHL, ERIC, Medline, and SocINDEX. The following keywords were used: "Nordic", "Norway", "Sweden", "Finland", "Denmark" or "Iceland"; and "healthcare", "nursing", or "medicine"; and "simulation", "teaching", "learning", "curriculum", "assessment", or "examination" (See Additional file 1). The search process was carried out during June 2016, and no limits on publication dates were set. The process of paper selection was conducted in accordance with the PRISMA flow diagram recommended by Schünemann [30] (See Fig. 1). Initially, a provisional sample of 2871 records emerged. The duplicates (1493 abstracts) were identified by SEH, resulting in 1378 records. All authors in this study separately reviewed the titles and abstracts of the articles against the following inclusion and exclusion criteria:

Included:

- Language: abstracts and papers in English, Norwegian, Danish, Swedish, Icelandic, or Finnish

- Empirical studies focusing on simulation in healthcare, nursing, or medicine

- Articles featuring empirical data material on simulation from at least one of the Nordic countries

- Peer-reviewed studies published before June 2016

- Empirical field: Studies from allied healthcare professions

Excluded:

- Abstracts from study protocols, books, and $\mathrm{PhD}$ theses

- Correspondence, Commentary, Letters or Debates, and Proceedings

Of the 1378 abstracts, 1360 were rejected because they did not meet the inclusion criteria, i.e., their focus was not on simulation or was about simulation but lacked empirical data, or there was no indication that the research was from one of the Nordic countries. A total of 18 full-text articles were retrieved and read by all authors,

Table $1 \mathrm{PICO}$

\begin{tabular}{ll}
\hline Participants & Healthcare and education \\
Intervention & Integrative review \\
Comparison & Norway, Finland, Denmark, Sweden, Iceland \\
Outcomes & Simulation-based learning \\
\hline
\end{tabular}




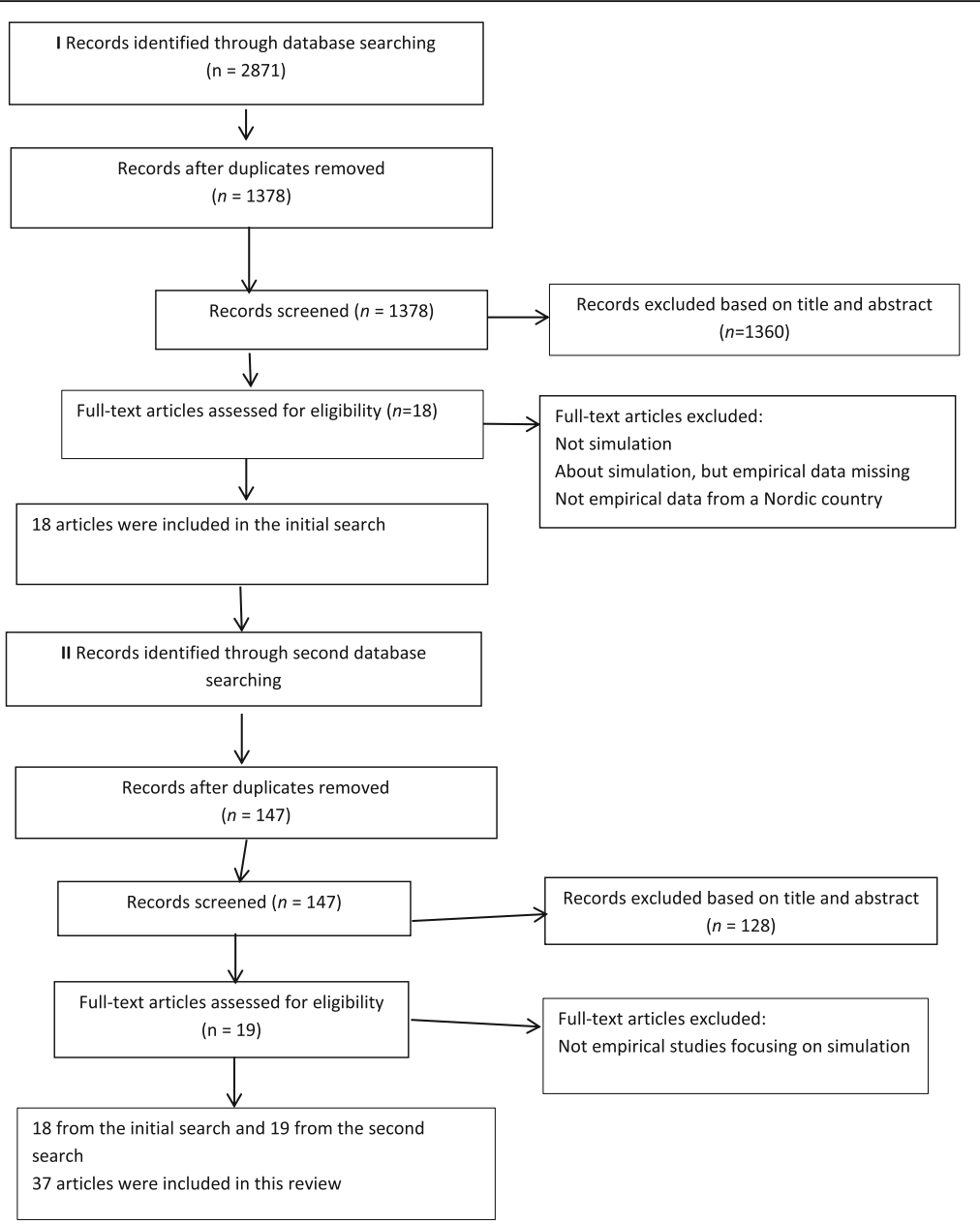

Fig. 1 PRISMA flow chart

and these were included in the final selection. A second search was conducted by SEH in Svemed+, a Scandinavian database and in Medic, a Finnish database, by authors MS and ER. A sample of 147 records were found, of which 128 were rejected because they did not meet the inclusion criteria, i.e., they did not include empirical data on simulation.

\section{Quality appraisal}

To assess the methodological quality of the studies selected, the "Mixed Method Appraisal Tool (MMAT)" [31] was used to evaluate quantitative and qualitative data [32]. The tool contains screening questions for all design methodologies, including qualitative, quantitative randomized controlled, quantitative non-randomized, quantitative descriptive, and mixed methods (Additional file 2). This tool offered a structured approach to the analysis of the research studies and assisted in the data abstraction and synthesis. To ensure that all authors possessed a similar understanding in the assessment of the studies, the tool was read and discussed before the assessment. Three of the authors (MS, ER, SEH) independently evaluated the quality of the selected studies, using the scoring system developed by Pluye et al. [31]. The format "Yes" for "present" and "No" for "not present" was used. At this stage, the authors decided to exclude eight review articles and one theoretical article because the appraisal tool was not constructed to fit these articles. The methodological quality was assessed by the "MMAT", and the included studies scored a range from 25 to $100 \%$. In total, 37 articles (18 from the initial search and 19 from the second search) were included in the quality appraisal.

\section{Data abstraction and synthesis}

The 37 studies included in the data abstraction and synthesis are summarized in Table 2. Since no meta-analytic approach was appropriate due to the diverse data set and methodologies used, a thematic analysis was undertaken [33]. To facilitate the analysis, data were extracted into an evidence table. The tabulation of qualitative and quantitative findings within a single matrix supported the synthesis of both narrative and statistical data [27]. First, the 37 included articles were carefully read to obtain an 
overview of the entirety of the material. Second, the results of the articles were coded according to similarities and differences; the coding was then verified for accuracy and relevance by all authors [33]. Third, codes were interpreted and then grouped into categories. Finally, themes were identified. The entire synthesis was discussed among all authors in several meetings (Skype calls), until consensus was reached on the final synthesis.

\section{Results}

\section{Characteristics of the literature}

This integrative review identified 37 studies of SBL from the Nordic countries. The first Nordic simulation study included in this review was published in 1992, and the number of studies published since then generally has increased each year (Fig. 2). The distribution of studies among countries was as follows: Finland 12, Norway 10, Denmark 9, and Sweden 6. We did not identify any studies from Iceland.

An assessment of the research design revealed that most studies used a qualitative or a descriptive design and that a variety of qualitative, quantitative, and mixed methods had been employed (Fig. 3). Qualitative methods included case studies, action research, essays, and focus group interviews, while quantitative methods included surveys and questionnaires, randomized/non-randomized control trials, pre-test and post-test measurements, and observations. Finland has published the greatest number of qualitative studies, and only Sweden and Norway have published randomized control trials.

The participants in the 37 included studies were primarily healthcare professionals and students. The majority of the studies $(n=15)$ included interprofessional teams with participants from several professions. The remaining studies had participants who were either paramedics or nurses/nursing students $(n=11)$, physicians/ medical students $(n=10)$, or personnel from pharmacies and health food stores $(n=1)$. The most commonly reported simulation modality [34] was manikins $(n=18)$, followed by simulated patients $(n=12)$, virtual reality $(n=4)$, and computer-based simulators, i.e., learner interaction with only a computer screen-based activity $(n=4)$. Three studies used two simulation modalities [35-37], two studies did not identify the type of simulation modality used $[38,39]$, and one study compared two simulation modalities [36].

\section{Themes}

The thematic analysis revealed five themes: technical skills, non-technical skills, user experience, educational aspects, and patient safety (Table 3).

\section{Technical skills}

This theme of technical skills included nine studies aiming to use simulation to learn technical skills, which is defined as "a skill that is required for the accomplishment of a specific task. In healthcare, it is about the knowledge, skills, and ability to accomplish a specific medical task; for example, inserting a chest tube or performing a physical examination" ([34] p. 39). The results in two of the studies demonstrated that participants improved their knowledge and skills in resuscitation (CPR) by using a manikin [40] or a virtual world multiplayer [41]. However, in a third study, participants exposed to stress performed resuscitation on a manikin with similar skill level as participants who were not exposed to stress [42]. When the quality of advanced CPR training using a manikin was compared to national guidelines, it was found to be satisfactory [43]. Another study evaluated the methods used to teach CPR in institutions that provided instructions at different levels to emergency medical providers. The results demonstrated that the hours of theoretical lessons or training on a manikin varied widely among institutions. In one third of the institutions, the instructor's visual estimation was

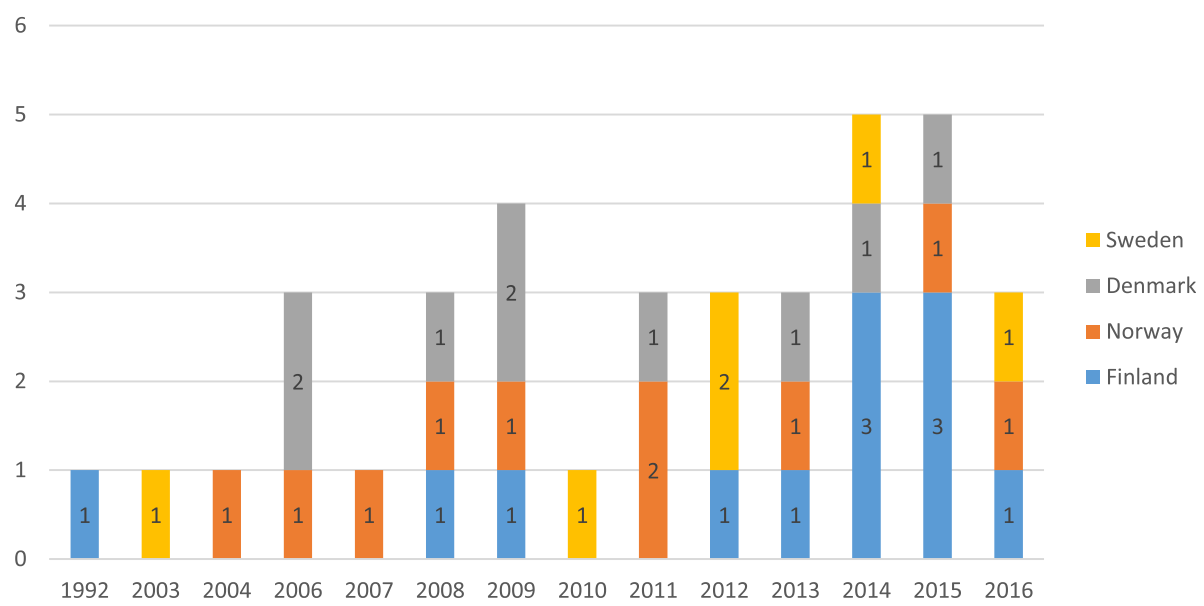

Fig. 2 Number of papers $(n=37)$ published per year per country from 1992 to 2016 


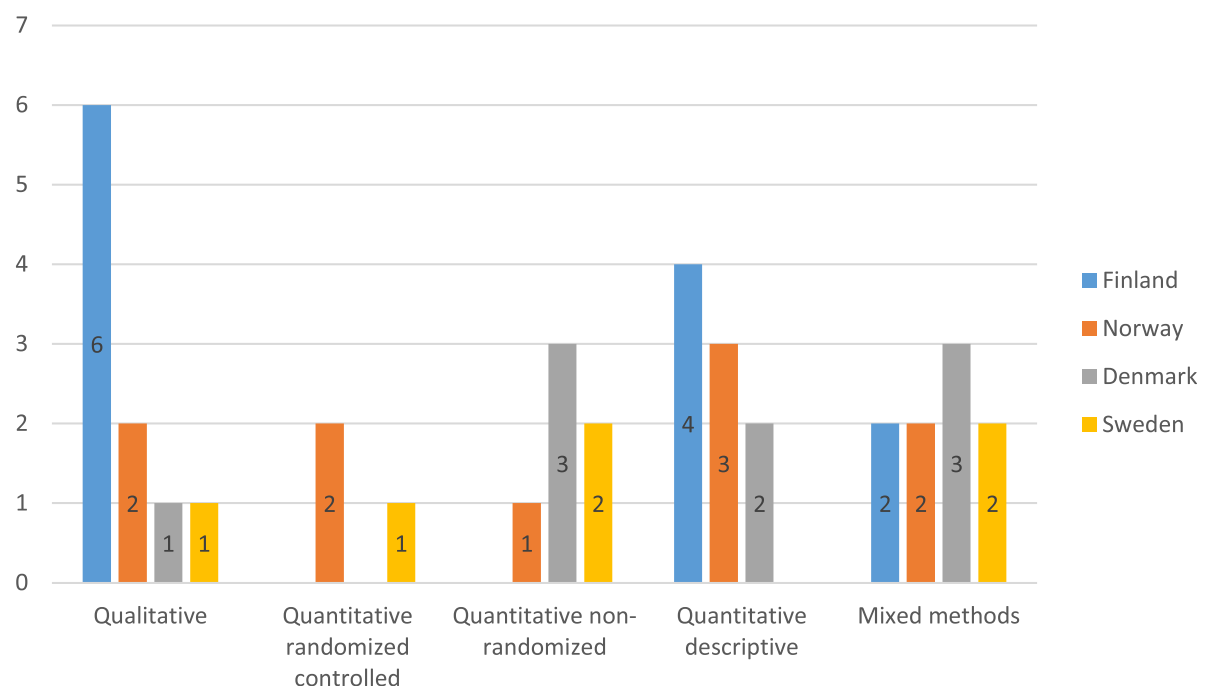

Fig. 3 Research design distributed among the Nordic countries $(n=37)$

the sole method used to teach chest compression rate and depth, while different technical methods were seldom used [44].

In one study, residents' skills were evaluated using a computer-based simulator (endoscopy simulator) [45]. The findings indicated that the simulation modality facilitated learning of endoscopic skills without morbidity and operating room inefficiency. The transfer of learned skills to clinical practice following SBL using a manikin was observed in the nursing management of patients requiring mechanical ventilation, but the scores of participants' factual knowledge, evaluated through a multiple-choice questionnaire, did not change statistically [46]. These results may suggest the separation of theory and practice; that is, simulation provides support to the acquisition of motor skills but not to cognitive factual knowledge, if these are learned separately. The evaluation of using a manikin in emergency situations as a method for interprofessional training in primary care found a significant increase in the participants' confidence in their own roles and in the order of necessary actions [47]. A study that used simulated customers who were purchasing a nutritional supplement to compare patient counseling performance in pharmacies and health food stores, demonstrated that the health food stores provided faster service compared to the pharmacies, a finding that is not surprising given the competing invested interest in the customers. However, information provided to customers in pharmacies was based on scientific facts, while well-being was the primary focus in health food stores [48].

\section{Non-technical skills}

Nine studies reported using SBL for training in nontechnical skills, defined as communication (patient-provider, team), leadership, teamwork, situational awareness, decision-making, resource management, safe practice, adverse event minimization/mitigation, and professionalism [34]. Four studies focused on uniprofessional team training in non-technical skills using SBL [49-52]. In medical education, simulation training resulted in improved communication skills in interviewing the simulated patient [49]. More than half of the nurses in a postoperative care study reported that a simulation-based communication course using a simulated patient improved their comprehension regarding how to use the communication model, and one third reported that their communication skills improved following completion of the course [50]. One study [52] found some inconsistencies in public health nurses' decision-making process using computer-based simulation with respect to the needs of the child and family; decisions were related more to the developmental stage of the child than to the unique needs of each family. A study that sought to describe physician behavior when serving as team leader in a simulated cardiac arrest during inter-hospital transfer, using a manikin, revealed deficiencies in junior physicians' skills as team leaders, especially concerning the delegation of tasks to other personnel [51]. Five studies focused on interprofessional team training in non-technical skills using SBL $[35,53-56]$ by using either a manikin $[53,55]$, a simulated patient [54], or both simulation modalities [35]. An evaluation of interprofessional education using a simulated patient in the areas of communication and collaboration revealed that nursing and medical students evaluated the education received very positively. The content and structure met the students' need for interprofessional education pertaining to ward rounds [56]. The results demonstrated that leaders used different techniques to convey their knowledge to the 


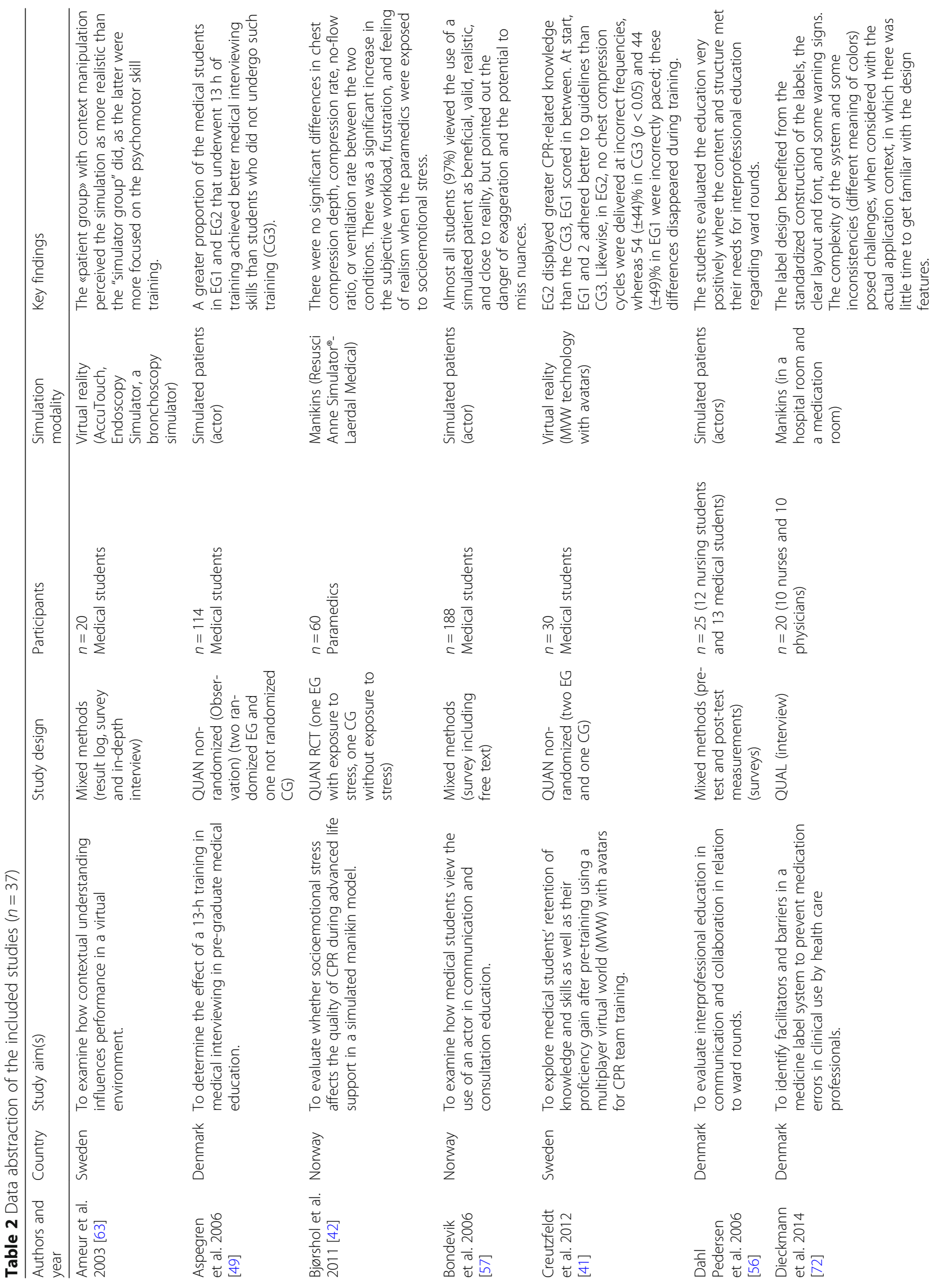




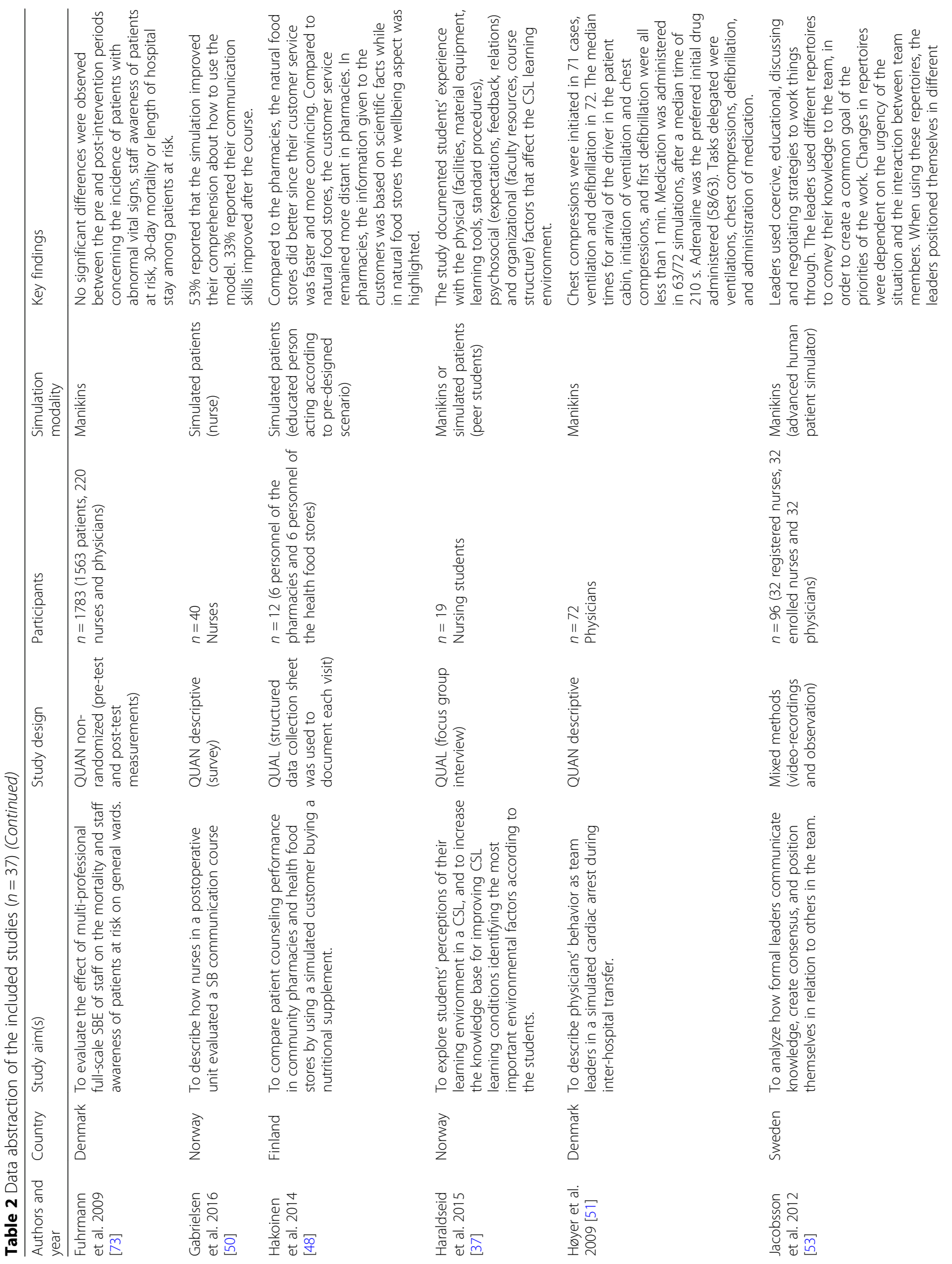




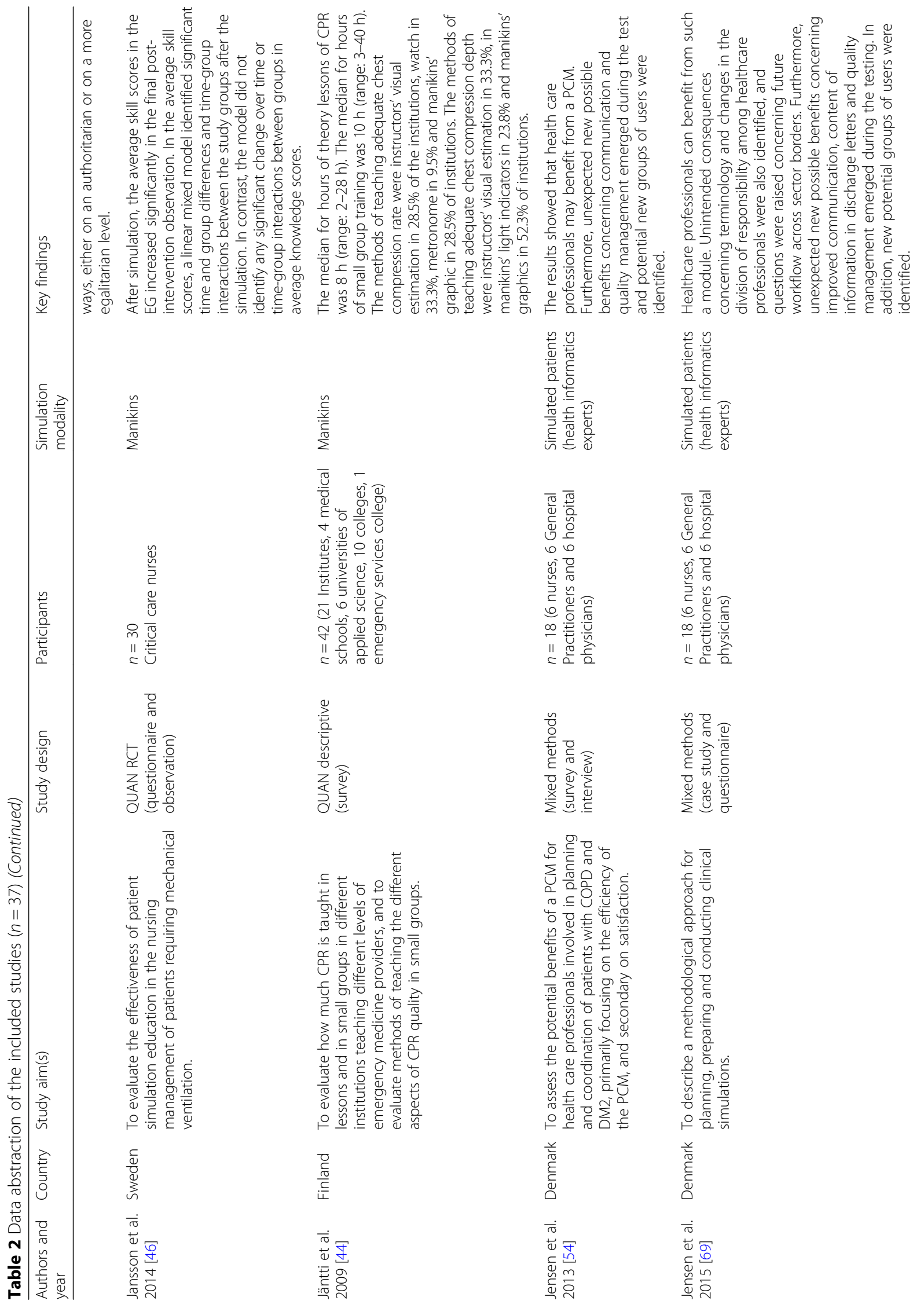




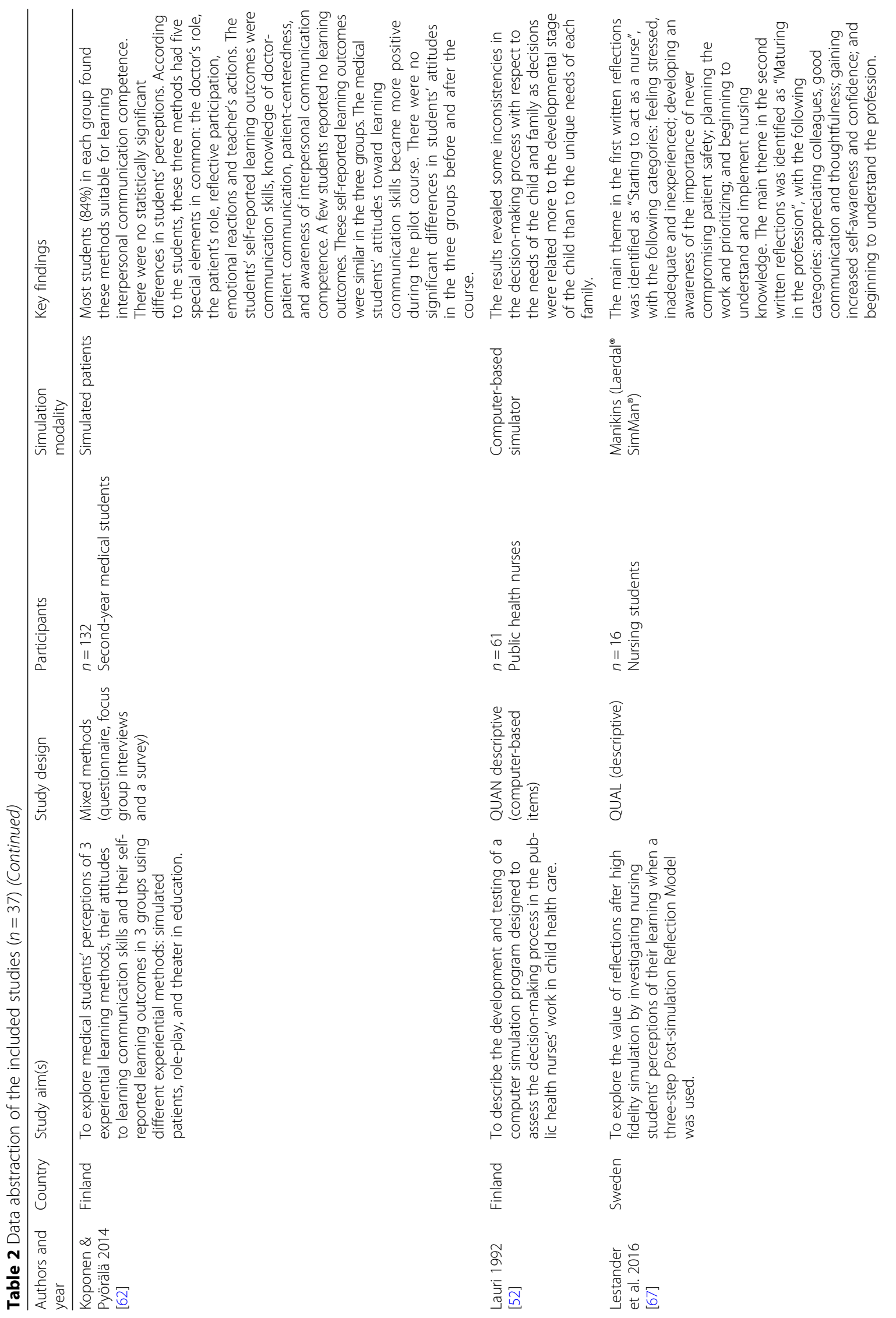




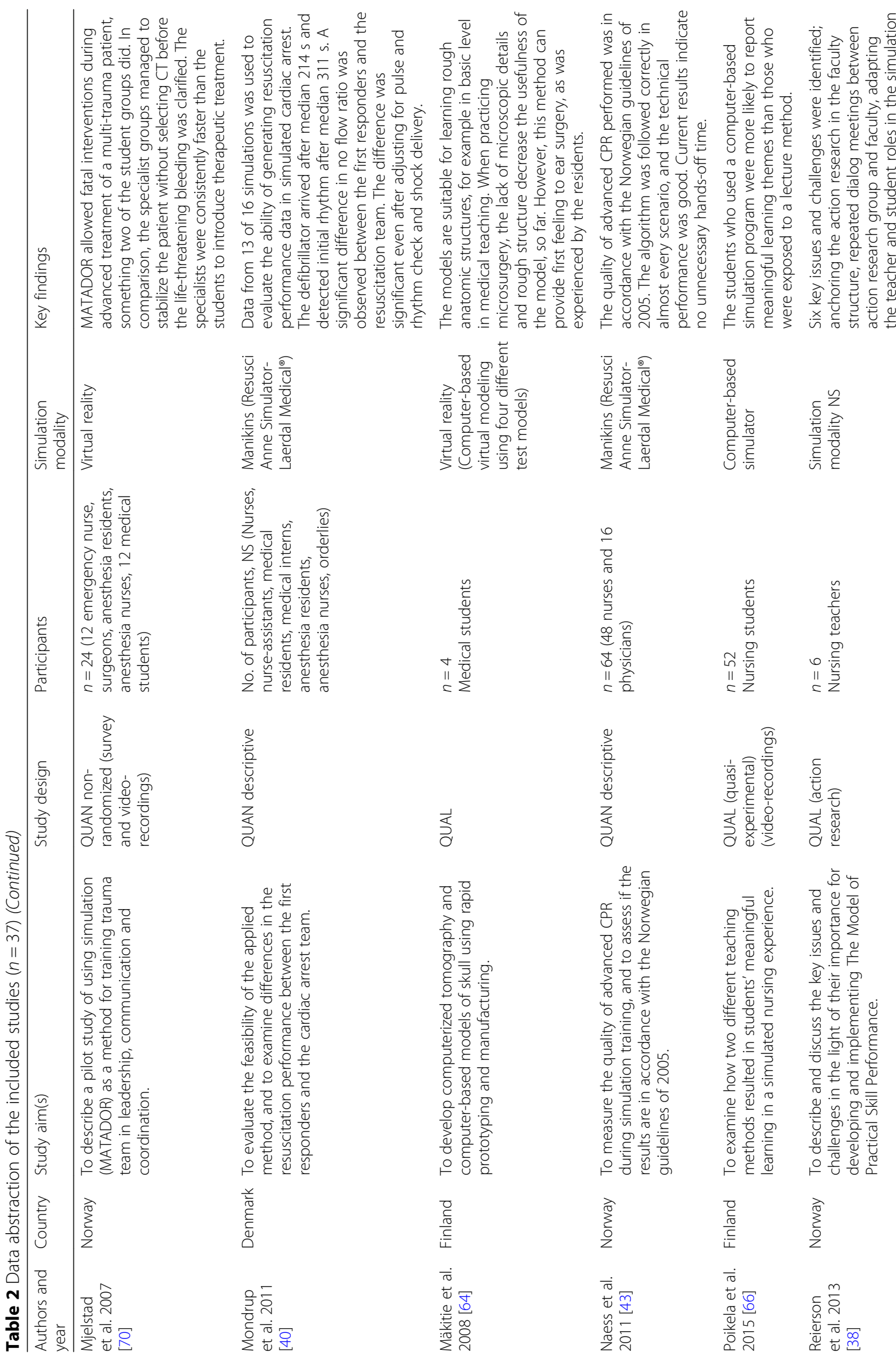




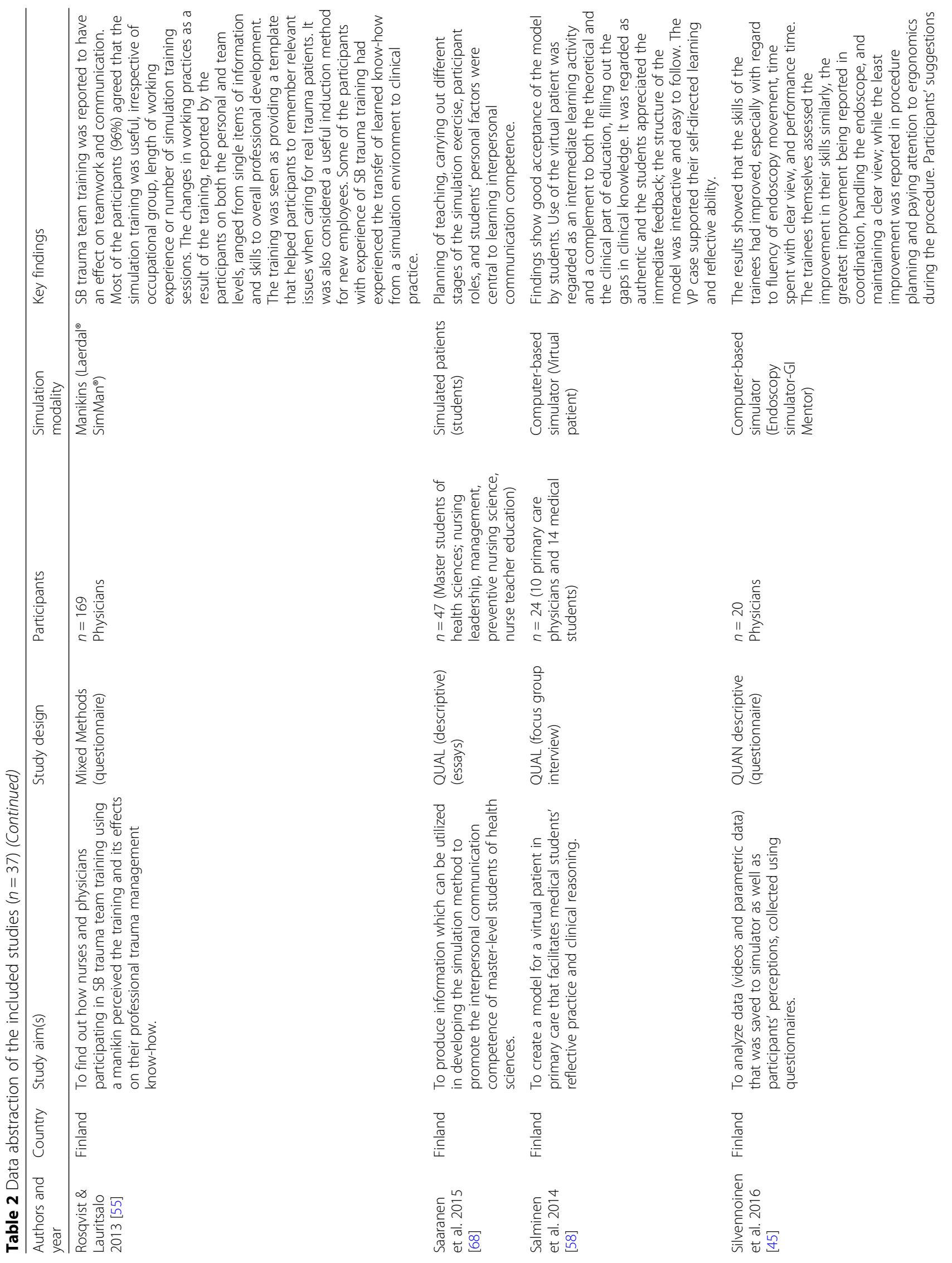




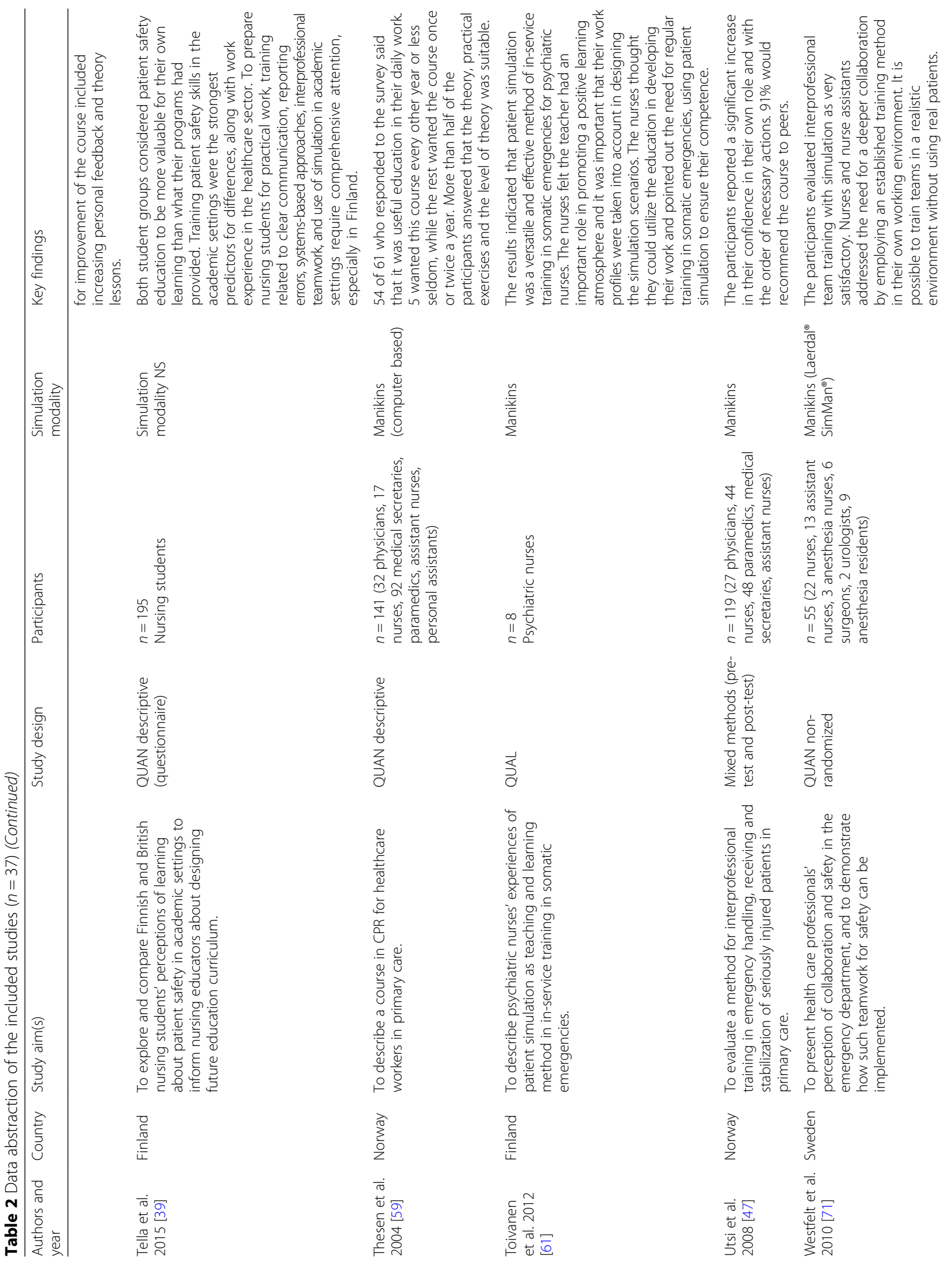




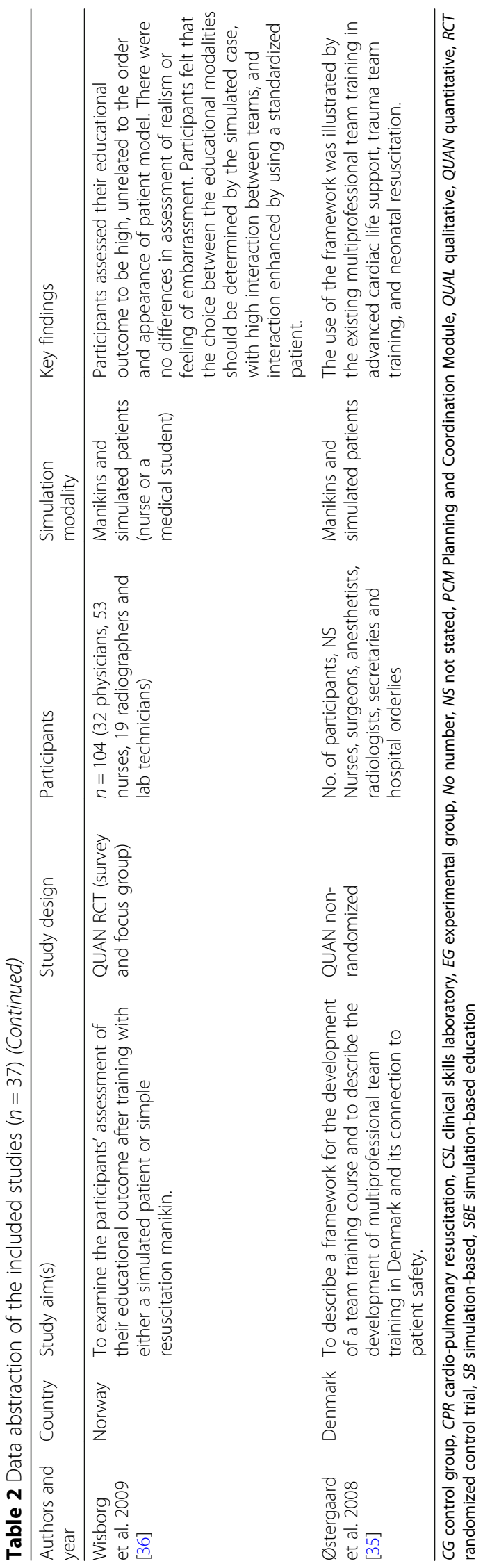


team in order to create a common goal relevant to work priorities. Changes in repertoires were dependent upon the situation and the interaction between team members [53]. Furthermore, Rosqvist and Lauritalo [55] found that most nurses and doctors evaluated the simulation training as useful, irrespective of occupational group, length of work experience, or number of simulation training sessions. The training helped them to remember relevant issues when caring for real trauma patients. In Jensen et al. [54], nurses and physicians benefited from a "Planning and Coordination Module" involved in the planning and coordination of patients with chronic diseases. Østergaard et al. [35] described a framework for the development of a multiprofessional team training course and its connection to patient safety. The use of the framework was illustrated by multiprofessional team training in advanced cardiac life support, trauma team training, and neonatal resuscitation.

\section{User experience}

The theme of user experience included nine studies describing participants' evaluation of and experience with simulation and the clinical skills laboratory as a learning environment. One study reported that almost all the medical students viewed the use of a simulated patient as beneficial, valid, realistic, and close to reality, but pointed out the danger of exaggeration and the potential to miss nuances [57]. Another study reported that the medical students regarded virtual simulation as an authentic intermediate learning activity with immediate feedback, a complement to the theoretical and clinical aspects of education, filling in the gaps in clinical knowledge and supporting their self-directed learning and reflective ability [58]. Interprofessional healthcare providers evaluated both theory and practical exercises in a CPR course using a manikin as useful forms of education in their daily work and expressed the desire for repetition of the course once or twice a year [59], which is in line with the European Resuscitation Council Guidelines for Resuscitation [60]. Psychiatric nurses evaluated the simulation with a manikin as a versatile and effective method of training in somatic emergencies and emphasized the teacher's important role in promoting a positive learning atmosphere, also noting that the nurses' work profiles were taken into account when designing the simulation scenarios [61]. Two studies evaluated user experience by comparing simulated patients with role-play and theater in education [62], or by comparing simulated patients and simple resuscitation manikins [36]. The studies reported that the participants assessed educational outcome to be high $[36,62]$, also indicating that it was unrelated to the order and appearance of the simulation modality [36, 62]. The participants in Wisborg et al. [36] felt that the choice between simulation modalities, i.e., manikin or simulated patient, should be determined by the simulated case. In Koponen and Pyörälä [62], the medical students' self-reported learning outcomes were communication skills, knowledge of doctor-patient communication, patient-centeredness, and enhanced awareness of interpersonal communication competence unrelated to the educational method. Another study reported that a group of medical students exposed to context manipulation (e.g., talking to the manikin as a real patient, reading the description of the patient, wearing operating clothes), perceived the simulation by using a bronchoscopy simulator as more realistic than another group did that focused only on skills training [63]. In Mäkitie et al. [64], four different computer-based virtual models were developed and tested on medical residents, who found the models suitable for learning rough anatomic structures. However, the lack of microscopic details and the rough structures decreased the usefulness of the model. Haraldseid et al. [37] reported that those factors affecting the clinical skills laboratory learning environment included students' experience of the physical (including manikins and simulated patients), psychosocial, and organizational factors.

\section{Educational aspects}

The seven studies in this theme were about designing SBL activities involving preparation (including choice of simulation modalities), briefing, simulation activity, debriefing or feedback, reflection, and evaluation [65]. In one quasi-experimental study related to nursing education, the findings revealed that nursing students who used a computer-based simulation program were more likely to report meaningful learning themes than those who first were exposed to the lecture method [66]. Lestander et al. [67] explored the value of reflection after simulation using a manikin when a three-step post-simulation reflection model was used (1. individual written reflection, 2. verbal group reflection, and 3 . individual written reflection). The main theme in the first reflection was "Starting to act as a nurse" and in the second "Maturing in the profession" indicating that repeated reflections stimulate and enhance student learning. Development and implementation of the "Practical Skill Performance model" in nursing education revealed six issues and challenges: anchoring the research in the faculty structure, repeated dialog meetings between research group and faculty, adapting teacher and student roles in the clinical skills laboratory, unequivocal understanding of the model as a theoretical and normative learning tool, curriculum consistency, and teachers' engagement and enthusiasm [38]. Simulation modality was not stated. In a study related to master's education coursework in health sciences, Saaranen et al. [68] found that planning of teaching, carrying out different stages of the simulation exercise by using simulated patients, participant roles, and students' personal factors were central to the attainment by the students of competence in communication. 
Table 3 Emerged categories and themes of Nordic simulation studies

Technical skills ( $n=9$ )
Categories
Resuscitation knowledge and skills
Resuscitation knowledge and skills
Pharmacist and health food clerk
technical skills
Knowledge and skills in nursing
management
Dose and methods of teaching
resuscitation
Resuscitation performance and
assessment of simulation method
Resuscitation knowledge and skills
Assessment of learning outcomes
and learners' feedback
Self-assessment of skills in
emergency care
Non-technical skills ( $n=9$ )
Categories

Communication skills assessment

Interprofessional communication and collaboration

Self-assessment of communication skills

Leadership and team skills in

cardiac arrest

Leadership skills in interprofessional teams

Communication and quality
management
skills related to patients with
chronic diseases
Assessment tool for decision-making
Self-assessment on trauma team
management know-how
Multiprofessional team training
User experience $(n=9)$

Categories

Participants' perception of the simulation

Participants' experience of learning outcome from simulation

Participants' experience on physical, psychosocial and organizational factors that affect the CSL learning environment

Participants' experience and selfassessment of three simulation modalities

Participants' experience with computer-based virtual simulation
Studies

Bjørshol et al. 2011 [42]

Creutzfeldt et al. 2012 [41]

Hakoinen et al. 2014 [48]

Jansson et al. 2014 [46]

Jäntti et al. 2009 [44]

Mondrup et al. 2011 [40]

Naess et al. 2011 [43]

Utsi et al. 2008 [47]

Studies

Aspegren et al. 2006 [49]

Dahl Pedersen et al. 2006 [56]

Gabrielsen et al. 2016 [50]

Høyer et al. 2009 [51]

Jacobsson et al. 2012 [53]

Jensen et al. 2013 [54]

Lauri $1992[52]$

Rosqvist \& Lauritsalo 2013 [55]

Østergaard et al. 2008 [35]

Studies

Ameur et al. 2003 [63]

Bondevik et al. 2006 [57]

Haraldseid et al. 2015 [37]

Koponen \& Pyörälä 2014 [62]

Mäkitie et al. 2008 [64]
Silvennoinen et al. 2016 [45]
Table 3 Emerged categories and themes of Nordic simulation studies (Continued)

\begin{tabular}{|c|c|}
\hline $\begin{array}{l}\text { Participants' experience on } \\
\text { virtual patients }\end{array}$ & Salminen et al. 2014 [58] \\
\hline $\begin{array}{l}\text { Participants' experience on } \\
\text { resuscitation course }\end{array}$ & Thesen et al. 2004 [59] \\
\hline $\begin{array}{l}\text { Participants' experience on } \\
\text { teaching and learning on } \\
\text { in-service training }\end{array}$ & Toivanen et al. 2012 [61] \\
\hline $\begin{array}{l}\text { Participants' experience and } \\
\text { self-assessment }\end{array}$ & Wisborg et al. 2009 [36] \\
\hline \multicolumn{2}{|l|}{ Educational aspects $(n=7)$} \\
\hline Categories & Studies \\
\hline $\begin{array}{l}\text { Planning, preparing and } \\
\text { conducting clinical simulations }\end{array}$ & Jensen et al. 2015 [69] \\
\hline $\begin{array}{l}\text { Simulation as a tool for } \\
\text { enhancing reflection }\end{array}$ & Lestander et al. 2016 [67] \\
\hline $\begin{array}{l}\text { Pilot testing of a virtual } \\
\text { reality simulation }\end{array}$ & Mjelstad et al. 2007 [70] \\
\hline $\begin{array}{l}\text { Assessing simulation } \\
\text { teaching methods }\end{array}$ & Poikela et al. 2015 [66] \\
\hline $\begin{array}{l}\text { Issues and challenges } \\
\text { with simulation implementation }\end{array}$ & Reierson et al. 2015 [38] \\
\hline $\begin{array}{l}\text { Curriculum development } \\
\text { on interpersonal communication } \\
\text { competences }\end{array}$ & Saaranen et al. 2015 [68] \\
\hline $\begin{array}{l}\text { Satisfaction with interprofessional } \\
\text { team training }\end{array}$ & Westfelt et al. 2010 [71] \\
\hline \multicolumn{2}{|l|}{ Patient safety $(n=3)$} \\
\hline Categories & Studies \\
\hline $\begin{array}{l}\text { Effects of intervention on } \\
\text { mortality rate }\end{array}$ & Fuhrmann et al. 2009 [73] \\
\hline $\begin{array}{l}\text { Prevention of medication and } \\
\text { systemic errors }\end{array}$ & Dieckmann et al. 2014 [72] \\
\hline $\begin{array}{l}\text { Development of a pedagogical } \\
\text { design of patient safety curriculum }\end{array}$ & Tella et al. 2015 [39] \\
\hline
\end{tabular}

Three studies focused on the development of interprofessional simulation. The first study described a methodological approach to the planning, preparing, and conducting of clinical simulations for doctors and nurses by using simulated patents. Unintended consequences concerning terminology and changes in the division of responsibility among healthcare professionals were identified and questions were raised concerning future workflow across sector borders [69]. The second study described a pilot study that employed virtual reality simulation to train trauma teams in leadership, communication, and coordination. When comparing students with specialists, it was not surprising that the students executed fatal interventions during treatment of a multi-trauma patient, while the specialist groups were faster and stabilized the patient without ordering a CT before life-threatening bleeding was clarified [70]. The third study presented healthcare professionals' perceptions of collaboration and safety in the emergency 
department and demonstrated how interprofessional teamwork could be implemented to improve safety [71]. Although the participants evaluated as very satisfactory the simulation training using a manikin, the nurses and nurse assistants addressed the need for deeper collaboration by employing an established training method in their own working environment.

\section{Patient safety}

The patient safety theme was the focus of three studies about prevention of medication and systemic errors [72], the effects of an intervention on mortality rates [73], and user experience in the pedagogical design of a patient safety curriculum [39]. A manikin was used in two of the studies $[72,73]$, while in the third study, the simulation modality was not stated [39]. Dieckmann et al. [72] found that the design of labels benefited from the standardized construction of the labels, while the complexity of the system and different meanings of colors posed challenges when considered in conjunction with the actual application context. Fuhrmann et al. [73] found no effect of multi-professional SBL, focusing on recognition and management of the deteriorating patient, on incidence of patients with abnormal vital signs, staff awareness of patients at risk, 30-day mortality, and length of hospital stay among patients at risk. Finally, Tella et al. [39] found that nursing students considered patient safety education that used simulation to be more valuable for their own learning than educational materials provided by their programs.

\section{Discussion}

The primary strength of SBL research in the Nordic literature is that the studies cover a wide range of themes, such as technical skills, non-technical skills, user experience, educational aspects, and patient safety. This demonstrates a broad interest in the field. In addition, most studies include interprofessional teams made up of healthcare professionals and students. We identified a number of simulation studies from all Nordic countries except Iceland. Among the Nordic countries, Finland stood out with the largest number of studies, especially those that used a variety of simulation modalities-for example, simulated patients [62], manikins [55], computer-based simulator [52], and virtual reality simulator [45]. Overall, an assessment of research designs revealed that qualitative and quantitative descriptive studies were employed most frequently.

The results from the nine studies categorized under the Technical skills theme demonstrated that skills can be improved by computer-based simulations. In these studies, the process of learning technical skills through simulation was researched in various contexts to measure and evaluate skills, educational methods, and safety as well as quality of service. However, only one of the studies showed a transfer of skills from simulation to clinical practice. These results are similar to the findings in other international review studies [3, 74-76], which reported improvement after SBL training in procedure and task performance, patient comfort and complication rates.

Regarding the theme Non-technical skills, nine studies demonstrated that interprofessional as well as uniprofessional training improved communication and collaboration skills when using SBL. The studies also revealed that leadership and communication styles depend on the context and participants' competence. This finding is congruent with the results of a previous non-Nordic study which found a number of factors that had an impact on the output of health professional teamwork training, i.e., the context in which the program was delivered, starting points of individual learners, and the opportunity to transfer new learning into practice [11]. A recent international review [74] also demonstrated positive patient outcomes after team and non-technical skills training, such as quicker intubation with fewer complications [77] and lower mortality [78]. However, none of the Nordic studies included in this review have reached such promising conclusions.

The nine studies categorized under the User experience theme demonstrated participant satisfaction with SBL and with the educational methods used, which were reputed to be valid and realistic. Results from studies of experiences by nursing students partially support the findings of our review, i.e., students were satisfied with SBL [9]. Unlike the results of our review, however, nursing students' experience in Foronda ([9], pp. e412) demonstrated that SBL also caused anxiety or stress, which might influence learning.

Under the theme Educational aspects, the seven studies revealed lessons learned when designing SBL. The results demonstrated promotion of learning and reflections that are meaningful in SBL compared to traditional lectures, challenges and possibilities for use in clinical practice, and simulation through the implementation of new models in skill training and the design of interprofessional team training. Additionally, the educational outcome was not dependent on the simulation modality, but rather, on the simulated case and the ability of the teacher to create a safe learning environment. The educational aspects of SBL, for example, design of SBL in the curriculum including reflections, and solving challenges with implementing SBL, are also emphasized as critical conditions for learning in the international literature $[79,80]$. An earlier international review has indeed shown that a strong instructional formatthat is, how a course is designed as well as feedback from the instructor-results in higher learning outcomes [81].

Only three studies were categorized under the theme Patient safety. Unfortunately, the intervention in Fuhrmann et al. [73] showed no improvement in terms of patient survival or staff awareness of patients at risk on general wards. Incorrect design of medication labels might put patient 
safety at risk, and additional patient safety education in nursing education would be valuable in preparing for clinical practice. Previous international research has supported the value of healthcare simulation in enhancing patient safety [82]. The expert group in Sollid et al. [82] identified the following five topics in healthcare simulation that contribute the most to improving patient safety: technical skills, non-technical skills, assessment, effectiveness, and system probing. Evidence of positive patient outcomes is, however, emerging in the literature, and non-Nordic systematic reviews have demonstrated small positive effects on patient-related outcomes and positive effects on learning and skills transfer to the clinical environment [74].

This review revealed that most of the Nordic simulation literature lacks robust research evidence that supports simulation as an effective educational method. RCT design was used only in Norway [36, 42] and Sweden [46], which implies that future simulation studies in the Nordic region may benefit from strengthening the research design and methodology. Furthermore, most of the studies that used simulation in learning technical skills included a small sample size and employed a descriptive design. Similar methodological and design shortcomings have been identified in the recent international literature [74, 75, 81]. Consequently, SBL research that addresses the lack of robust research design and methodology should continue to point in the right direction. Interprofessional team training using SBL for non-technical skills has become increasingly important because of the changing healthcare system, both in and out of the hospital as well as in primary care [83]. Patient care becomes a series of transitions from home to hospital to rehabilitation facilities and back to home again, necessarily engaging a host of multidisciplinary professionals-nurses, doctors, etc., who must work together to provide a seamless web of health services. Five of the nine studies in the Non-technical skills theme were performed in Denmark, which suggest a need for further research in this theme in the other Nordic countries. Another gap identified is the lack of Danish studies in the User experience theme; only one was identified (Table 2). Furthermore, limited research that addressed patient safety was found. Fuhrmann et al.'s [73] considerable work linking the effects of simulation to patient outcomes may provide direction for future targeted interventions to decrease adverse events and patient mortality. However, evidence of patient outcomes linked to SBL is very difficult to demonstrate because of many other external medical factors that can influence patient outcomes and that are unrelated to the effects of SBL [84]. Therefore, the following question is anticipated: Is it really necessary to demonstrate patient outcomes to support the use of SBL in healthcare?

\section{Future directions}

No study identified a cross-country comparison of studies using simulation in the Nordic countries. This stands out as an important area for future research and corresponds well with the NordForsk strategy for improved research collaboration [25]. The goal of the NordForsk strategy is to enhance the quality, impact, and cost-efficiency of Nordic research and research infrastructure collaboration, for example, by strengthening integrated cross-sectoral research and supporting the establishment of new joint Nordic research infrastructures. Another gap identified is the scarce number of studies from the primary care setting or from a combination of the specialized and primary care settings. The lack of simulation studies that use a primary care perspective mirrors findings from the international literature [85], adding emphasis to the importance of knowledge development in this area. According to our review, no research exists that focuses on valid assessment methods, scales, and rating instruments for non-technical skills, all of which would enable cross-country research collaboration in the Nordic countries. There is also a lack of simulation research that studies cost-effectiveness in the Nordic countries. The demonstration of cost-effectiveness could increase the resources directed to SBL. In this review, 11 studies stated funding from different private and public funds. Another gap identified in the Nordic literature is the lack of research on in situ trauma team simulation training in the hospital setting. This type of research would be beneficial because it is conducted in the actual patient care environment, using equipment and resources from that unit, and involving actual members of the healthcare team [86]. In situ training makes the learning context authentic, possibly reinforcing the learning experience.

\section{Limitations}

The review has several limitations. Our search strategy did not identify all critical articles. Only five international, one Nordic, and one Finnish databases were searched. Other databases may have revealed additional articles. The review focused exclusively on peer-reviewed simulation studies in healthcare education in the Nordic countries. Due to inclusion criteria, gray literature from the Nordic countries was not included. However, we believe that this integrative review provides new insights and offers possible directions for future research. A promising strength of this review is the close collaboration among the authors, who represented the Nordic countries in all phases of the review process, especially in the thematic analysis.

\section{Conclusion}

Most Nordic research literature on SBL has employed a qualitative or a descriptive design that includes interprofessional or uniprofessional teams and relates to technical skills, non-technical skills, user experience, educational 
aspects, and patient safety. Shortcomings in simulation research in the Nordic countries include a lack of randomized control trials and evidence that supports simulation as an educational method, as well as a dearth of studies focusing on patient safety, the primary care setting, or a combination of specialized and primary care settings. Suggested directions for future research include strengthening the design and methodology of SBL studies, incorporating a cross-country comparison of studies using simulation in the Nordic countries, and studies combining specialized and primary care settings.

\section{Additional files}

Additional file 1: Search in databases, terms, and hits. (DOCX 18 kb)

Additional file 2: Mixed methods appraisal tool [32] used for the quality appraisal $(N=37)$. (DOCX $48 \mathrm{~kb})$

\section{Funding}

The University of Stavanger funded this study.

\section{Availability of data and materials}

All data generated or analyzed during this study are included in this published article [and its supplementary information files].

\section{Authors' contributions}

SEH, MS, and ER searched databases and all authors separately reviewed the titles and abstracts. SEH, MS, and ER evaluated the quality of the selected studies. All authors participated in the thematic analysis. SEH wrote the first version of the manuscript. All authors read and approved the final manuscript.

\section{Ethics approval and consent to participate}

Not applicable

\section{Consent for publication}

Not applicable

\section{Competing interests}

The authors declare that they have no competing interests.

\section{Publisher's Note}

Springer Nature remains neutral with regard to jurisdictional claims in published maps and institutional affiliations.

\section{Author details}

${ }^{1}$ Faculty of Health Sciences, University of Stavanger, Stavanger, Norway. ${ }^{2}$ Department of Surgery, Stavanger University Hospital, Stavanger, Norway. ${ }^{3}$ Faculty of Health and Social Sciences, University of Southeast Norway, Porsgrunn, Norway. ${ }^{4}$ School of Health and Social Studies, JAMK University of Applied Sciences, Jyväskylä, Finland. ${ }^{5}$ Department of Teacher Education, University of Jyväskylä, Jyväskylä, Finland. ${ }^{6}$ Department of Education and Science, The Center of Medical Expertise, Central Finland Healthcare District, Jyväskylä, Finland. ${ }^{7}$ Department of Clinical Science and Education, Karolinska Institutet, Södersjukhuset, Stockholm, Sweden.

Received: 15 January 2018 Accepted: 18 June 2018 Published online: 04 July 2018

\section{References}

1. Kohn LT, Corrigan J, Donaldson MS. To err is human: building a safer health system. Washington, D.C.: National Academy Press; 2000.

2. Aebersold M. The history of simulation and its impact on the future. AACN Advanced Critical Care. 2016;27:56-61. https://doi.org/10.4037/ aacnacc2016436
3. Griswold-Theodorson S, Ponnuru S, Dong C, Szyld D, Reed T, McGaghie WC. Beyond the simulation laboratory: a realist synthesis review of clinical outcomes of simulation-based mastery learning. Academic Medicine: Journal Of The Association Of American Medical Colleges. 2015;90:1553-60. https://doi.org/10.1097/ACM.0000000000000938.

4. Hegland PA, Aarlie H, Strømme H, Jamtvedt G. Simulation-based training for nurses: systematic review and meta-analysis. Nurse Educ Today. 2017;54:6-20. https://doi.org/10.1016/j.nedt.2017.04.004.

5. Kunst $\mathrm{E}$, Mitchell M, Johnston A. Manikin simulation in mental health nursing education: an integrative review. Clinical Simulation in Nursing. 2016;12:484-95. https://doi.org/10.1016/j.ecns.2016.07.010.

6. McGaghie WC, Issenberg SB, Barsuk JH, Wayne DB. A critical review of simulation-based mastery learning with translational outcomes. Med Educ 2014;48:375-85. https://doi.org/10.1111/medu.12391.

7. Palaganas J, Brunette V, Winslow B. Prelicensure simulation-enhanced interprofessional education: a critical review of the research literature. Simul Healthc. 2016:11:404-18.

8. Villemure C, Tanoubi I, Georgescu LM, Dubé J-N, Houle J. An integrative review of in situ simulation training: implications for critical care nurses. Canadian Journal of Critical Care Nursing. 2016;27:23-31.

9. Foronda C, Liu S, Bauman E. Evaluation of simulation in undergraduate nurse education: an integrative review. Clinical Simulation in Nursing. 2013; 9:e409-16. https://doi.org/10.1016/j.ecns.2012.11.003.

10. Fernandez R, Vozenilek JA, Hegarty CB, Motola I, Reznek M, Phrampus PE, et al. Developing expert medical teams: toward an evidence-based approach. Acad Emerg Med. 2008;15:1025-36.

11. Eddy K, Jordan Z, Stephenson M. Health professionals' experience of teamwork education in acute hospital settings: a systematic review of qualitative literature. JBI Database Of Systematic Reviews And Implementation Reports. 2016;14:96-137. https://doi.org/10.11124/JBISRIR-2016-1843.

12. Wali E, Pinto JM, Cappaert M, Lambrix M, Blood AD, Blair EA, et al. Teaching professionalism in graduate medical education: what is the role of simulation? Surgery. 2016;160:552-64. https://doi.org/10.1016/j.surg.2016.03.026.

13. Lopreiato J, Sawyer T. Simulation-based medical education in pediatrics. Acad Pediatr. 2015;15:134-42. https://doi.org/10.1016/j.acap.2014.10.010.

14. McGaghie WC, Issenberg SB, Petrusa ER, Scalese RJ. A critical review of simulation-based medical education research: 2003-2009. Medical Education. 2010:44:50-63. doi: https://doi.org/10.1111/j.1365-2923.2009.03547.x.

15. Zendejas B, Brydges R, Wang A, Cook D. Patient outcomes in simulation-based medical education: a systematic review. JGIM: Journal of General Internal Medicine. 2013;28:1078-89. https://doi.org/10.1007/s11606-012-2264-5. 16.

16. Khanduja KP, Dylan Bould M, Naik VN, Hladkowicz E, Boet S. The role of simulation in continuing medical education for acute care physicians: a systematic review. Crit Care Med. 2015;43:186-93. https://doi.org/10.1097/ CCM.0000000000000672.

17. Moglia A, Ferrari V, Morelli L, Ferrari M, Mosca F, Cuschieri A. A systematic review of virtual reality simulators for robot-assisted surgery. Eur Urol. 2016; 69:1065-80. https://doi.org/10.1016/j.eururo.2015.09.021.

18. Willaert W, Aggarwal R, Herzeele I, Cheshire N, Vermassen F. Recent advancements in medical simulation: patient-specific virtual reality simulation. World J Surg. 2012;36:1703-12. https://doi.org/10.1007/s00268-012-1489-0.

19. Østergaard ML, Ewertsen C, Konge L, Albrecht-Beste E, Bachmann Nielsen M. Simulation-based abdominal ultrasound training - a systematic review. Ultraschall Med. 2016;37:253-61. https://doi.org/10.1055/s-0042-100452.

20. Kyriakoulis K, Patelarou A, Laliotis A, Wan AC, Matalliotakis M, Tsiou C, et al. Educational strategies for teaching evidence-based practice to undergraduate health students: systematic review. Journal Of Educational Evaluation For Health Professions. 2016;13:13-34.

21. Motola I, Devine LA, Chung HS, Sullivan JE, Issenberg SB. Simulation in healthcare education: a best evidence practical guide. AMEE Guide No 82 Medical Teacher. 2013;35:e1511-e30. https://doi.org/10.3109/0142159X.2013. 818632

22. Ryall T, Judd B, Gordon C. Simulation-based assessments in health professional education: a systematic review. J Multidiscip Healthc. 2016;9: 69-82. https://doi.org/10.2147/JMDH.S92695.

23. Bland A, Topping A, Wood B. A concept analysis of simulation as a learning strategy in the education of undergraduate nursing students. Nurse Educ Today. 2011;31:664-70. https://doi.org/10.1016/j.nedt.2010.10.013.

24. Husebø S, Rystedt H. Simulering innen helsefag [Simulation in healthcare]. In: Aase K, editor. Pasientsikkerhet: teori og praksis i helsevesenet [Patient safetytheory and practice]. 2nd. Oslo: Universitetsforlaget; 2015. p. 155-171. 
25. NordForsk. About Nordforsk 2017. https://www.nordforsk.org/en. Accessed 15 June 2017.

26. Evans D. Overview of methods. In: Roe CW, editor. Reviewing research evidence for nursing practice: systematic reviews. Oxford: Blackwell Publication; 2007.

27. Whittemore R, Knafl K. The integrative review: updated methodology. J Adv Nurs. 2005;52:546-53.

28. Lefebvre C, Manheimer E, Glanville J. Searching for studies. In: Higgins JPT, Green S, editors. Cochrane Handbook for Systematic Reviews of Interventions. 5.1.0: the Cochrane collaboration; 2011.

29. Elliot D. Seaching literature sources. In: Schneider ZED, Lobiondo-Wood G, Haber J, editors. Nursing research: methods critical appraisal and utilisation. 2nd ed. Marrickville: Elsevier; 2003. p. 44-5.

30. Schünemann H, Oxman A, Higgins J, Vist G, Glasziou P, Guyatt G. Presenting results and 'summary of findings' tables (CH 11): The Cochrane Collaboration; 2011. http://training.cochrane.org/handbook. Accessed 9 May 2016.

31. Pluye P, Robert E, Cargo M, Bartlett G, O'Cathain A, Griffiths F, et al. Proposal: a mixed methods appraisal tool for systematic mixed studies reviews. Montreal: Department of Family Medicine, McGill University; 2011. http:// mixedmethodsappraisaltoolpublic.pbworks.com/w/page/24607821/ FrontPage. Accessed 9 May 2016

32. Pluye $\mathrm{P}$, Hong Q. Combining the power of stories and the power of numbers: mixed methods research and mixed studies reviews. Annu Rev Public Health. 2014;35:29-45.

33. Braun V, Clarke V. Using thematic analysis in psychology. Qual Res Psychol. 2006;3:77-101. https://doi.org/10.1191/1478088706qp0630a.

34. Lopreiato JO, Downing D, Gammon W, Lioce L, Sittner BJ, Slot V, et al. Healthcare simulation dictionary. 2016. http://www.ssih.org/dictionary. Accessed 16 May 2017.

35. Østergaard HT, Østergaard D, Lippert A. Implementation of team training in medical education in Denmark. Postgrad Med J. 2008;84:507-11. https://doi. org/10.1136/qshc.2004.009985.

36. Wisborg T, Brattebö G, Brinchmann-Hansen Å, Hansen HS. Mannequin or standardized patient: participants' assessment of two training modalities in trauma team simulation. Scandinavian Journal of Trauma, Resuscitation and Emergency Medicine. 2009;17:1-4. https://doi.org/10.1186/1757-7241-17-59.

37. Haraldseid C, Friberg F, Aase K. Nursing students' perceptions of factors influencing their learning environment in a clinical skills laboratory: a qualitative study. Nurse Educ Today. 2015;35:e1-6. https://doi.org/10.1016/j. nedt.2015.03.015.

38. Reierson IÅ, Hvidsten A, Wighus M, Brungot S, Bjørk IT. Key issues and challenges in developing a pedagogical intervention in the simulation skills center-an action research study. Nurse Educ Pract. 2013;13:294-300. https://doi.org/10.1016/..nepr.2013.04.004.

39. Tella S, Smith N-J, Partanen P, Turunen H. Learning patient safety in academic settings: a comparative study of Finnish and British nursing students' perceptions. Worldviews On Evidence-Based Nursing / Sigma Theta Tau International, Honor Society Of Nursing. 2015;12:154-64. https:// doi.org/10.1111/wvn.12088

40. Mondrup F, Brabrand M, Folkestad L, Oxlund J, Wiborg KR, Sand NP, et al. In-hospital resuscitation evaluated by in situ simulation: a prospective simulation study. Scandinavian Journal of Trauma, Resuscitation and Emergency Medicine. 2011;19:1-6. https://doi.org/10. 1186/1757-7241-19-55

41. Creutzfeldt J, Hedman L, Felländer-Tsai L. Effects of pre-training using serious game technology on CPR performance-an exploratory quasiexperimental transfer study. Scandinavian Journal of Trauma, Resuscitation and Emergency Medicine. 2012;20:1-9.

42. Bjørshol CA, Myklebust H, Nilsen KL, Hoff T, Bjørkli C, lllguth E, et al. Effect of socioemotional stress on the quality of cardiopulmonary resuscitation during advanced life support in a randomized manikin study. Crit Care Med. 2011;39:300-4. https://doi.org/10.1097/CCM.0b013e3181ffe100.

43. Naess M, Ellingsen T-L, Trudvang SP, Rökvam AS. The quality of advanced cardiopulmonary resuscitation during simulation training. Sykepleien Forskning. 2011;6:340-7. https://doi.org/10.4220/sykepleienf.2011.0190.

44. Jäntti $H$, Silfvast $T$, Turpeinen A, Paakkonen $H$, Uusaro A. Nationwide survey of resuscitation education in Finland. Resuscitation. 2009;80:1043-6. https:// doi.org/10.1016/j.resuscitation.2009.05.027.

45. Silvennoinen M, Mattila A, Korhonen H, Mrena J, Peräaho M, Mecklin J-P. Ruoansulatuskanavan tähystysten monimyoto-opetus kirurgian ja sisätautien runkokoulutuksessa [Blended training approach applied in endoscopy course for surgical and internal medicine residents]. Suomen lääkärilehti. 2016;14:998-1002.

46. Jansson MM, Ala-Kokko TI, Ohtonen PP, Meriläinen MH, Syräälä HP, Kyngäs HA. Human patient simulation education in the nursing management of patients requiring mechanical ventilation: a randomized, controlled trial. Am J Infect Control. 2014;42:271-6. https://doi.org/10.1016/j.ajic.2013.11.023.

47. Utsi R, Brandstorp H, Johansen K, Wisborg T. Training in multiprofessional emergency medicine in primary health care. Tidsskr Nor Laegeforen. 2008; 128:1057-9.

48. Hakoinen S, Honkala A, Vuorela M, Mononen N. Itseoidon sudenkuopat -tapauksena ravintolisa. Apteekkien ja luontaituotekauppojen neuvonnan vertaliua haamuasiakastapausten avulla [Counseling self-medication customer in pharmacies and health food stores-a mystery shopping study on a nutritional supplement] Dosis: farmaseuttinen aikakauskirja. 2014;30:48-57.

49. Aspegren K, Lönberg Madsen P. Effect of 13 hours of medical interview training in undergraduate medical education. Ugeskr Laeger. 2006;168:2445-9.

50. Gabrielsen AK, Karlsen M-MW, Falch AL, Stubberud D-G. Communication training with simulation. Sykepleien Forskning. 2016;11:184-92. https://doi. org/10.4220/Sykepleienf.2016.57832.

51. Høyer CB, Christensen EF, Eika B. Junior physician skill and behaviour in resuscitation: a simulation study. Resuscitation. 2009:80:244-8. https://doi. org/10.1016/j.resuscitation.2008.10.029.

52. Lauri S. Using a computer simulation program to assess the decisionmaking process in child health care. Comput Nurs. 1992;10:171-7.

53. Jacobsson M, Hargestam M, Hultin M, Brulin C. Flexible knowledge repertoires: communication by leaders in trauma teams. Scandinavian Journal of Trauma, Resuscitation and Emergency Medicine. 2012;20:1-9. https://doi.org/10.1186/1757-7241-20-44.

54. Jensen S, Vingtoft S, Nøhr C. Benefits of a clinical planning and coordination module: a simulation study. Studies In Health Technology And Informatics. 2013;183:220-4.

55. Rosqvist E, Lauritsalo $\mathrm{S}$. Traumatiimin simulaatiokoulutuksesta myönteisiä kokemuksia [Experiences of simulation-based trauma teamtraining from the Central Hospital of Central Finland]. Suomen Lääkärilehti. 2013;6:414-8.

56. Dahl Pedersen B, Kuch Poulsen I, Ringsted CV, Schroeder TV. Interprofessional communication and cooperation training in ward rounds for medical and nursing students: a pilot project. Ugeskr Laeger. 2006;168:2449-51.

57. Bondevik GT, Smith-Sivertsen T, Baerheim A. Use of actors to train medical students in communication skills. Tidsskr Nor Laegeforen. 2006;126:2118-21.

58. Salminen $\mathrm{H}$, Zary N, Björklund $\mathrm{K}$, Toth-Pal E, Leanderson C. Virtual patients in primary care: developing a reusable model that fosters reflective practice and clinical reasoning. J Med Internet Res. 2014;16:e3-e. https://doi.org/10. 2196/jmir.2616.

59. Thesen J, Mosevoll TD, Malterud K. Cardiopulmonary resuscitation in municipal health services - a simple program for training and maintenance. Tidsskr Nor Laegeforen. 2004;124:322-3.

60. Greif R, Lockey AS, Conaghan P, Lippert A, De Vries W, Monsieurs KG, et al. European resuscitation council guidelines for resuscitation. Resuscitation. 2015;95:288-301. https://doi.org/10.1016/j.resuscitation.2015.07.032.

61. Toivanen S, Turunen $H$, Paakkonen $H$, Tossavainen K. Potilassimulaatio somaattisten hätätilanteiden opetusmenetelmänä - psykiatristen sairaanhoitajien kokemuksia täydennyskoulutuksesta [Patient simulation as an educational methods in somatic emergencies- psychiatric nurses' experiences from in-service training]. Tutkiva Hoitotyö. 2012;10:16-24.

62. Koponen J, Pyörälä E. Kokemukselliset oppimismenetelmät edistävät lääketieteen opiskelijoiden vuorovaikutustaitoja [Experiential learning methods improve the communication skills of medical students]. Suomen Lääkärilehti. 2014;6:387-92.

63. Ameur S, Carlander K, Grundström K, Hallberg P, Lundgren K, Lundquist PG, et al. Learning bronchoscopy in simulator improved dexterity rather than judgement. Lakartidningen. 2003;100:2694-9.

64. Mäkitie A, Kanerva J, Paloheimo M, Paloheimo K, Björkstrand R, Tuomi J, et al. Uusi kallomalli korvaporauksen harjoitteluun. Duodecim; Lääketieteellinen Aikakauskirja. 2008;124:1979-85.

65. Nestel D, Gough S. Designing simulation-based learning activities: a systematic approach. In: Nestel D, Jolly B, Watson M, Kelly M, editors. Healthcare simulation education : evidence, Theory \& Practice. Chicester: Wiley; 2017. p. 135-142.

66. Poikela P, Ruokamo H, Teräs M. Comparison of meaningful learning characteristics in simulated nursing practice after traditional versus computer-based simulation method: a qualitative videography study. Nurse Educ Today. 2015;35:373-82. https://doi.org/10.1016/j.nedt.2014.10.009. 
67. Lestander Ö, Lehto N, Engström Å. Nursing students' perceptions of learning after high fidelity simulation: effects of a three-step post-simulation reflection model. Nurse Educ Today. 2016;40:219-24. https://doi.org/10. 1016/j.nedt.2016.03.011.

68. Saaranen T, Vaajoki A, Kellomäki M, Hyvärinen M-L. The simulation method in learning interpersonal communication competence-experiences of masters' degree students of health sciences. Nurse Educ Today. 2015;35:e8-e13 $1 \mathrm{p}$. https://doi.org/10.1016/.jnedt.2014.12.012.

69. Jensen S, Kushniruk AW, Nøhr C. Clinical simulation: a method for development and evaluation of clinical information systems. J Biomed Inform. 2015;54:65-76. https://doi.org/10.1016/j.jbi.2015.02.002.

70. Mjelstad S, Halvorsrud R, Bach-Gansmo E. MATADOR—a system for netbased trauma team training. Akuttjournalen. 2007;15:6-10.

71. Westfelt P, Hedsköld M, Pukk-Härenstam K, Svensson R-M, Wallin C-J. Effecient training in cooperation within your own emergency department. With patient simulation and eller skilled trainers. Lakartidningen. 2010;107:685-9.

72. Dieckmann P, Clemmensen MH, Sørensen TK, Kunstek P, Hellebek A. Identifying facilitators and barriers for patient safety in a medicine label design system using patient simulation and interviews. Journal Of Patient Safety. 2014;12:210-22.

73. Fuhrmann L, Perner A, Klausen TW, Østergaard D, Lippert A. The effect of multi-professional education on the recognition and outcome of patients at risk on general wards. Resuscitation. 2009;80:1357-60. https://doi.org/10. 1016/j.resuscitation.2009.07.002.

74. Masiello I, Mattsson A. Simuleringsträning ger ökad kunskap och bättre färdigheter. Lakartidningen. 2017;114:1-5.

75. Cook DA, Brydges R, Zendejas B, Hamstra SJ, Hatala R. Mastery learning for health professionals using technology-enhanced simulation: a systematic review and meta-analysis. Academic medicine. 2013;88:1178-86. https://doi. org/10.1097/ACM.0b013e31829a365d.

76. Cook DA, Hatala R, Brydges R, Zendejas B, Szostek JH, Wang AT, et al. Technology-enhanced simulation for health professions education: a systematic review and meta-analysis. JAMA. 2011;306:978-88. https://doi. org/10.1001/jama.2011.1234.

77. Boet S, Bould MD, Fung L, Qosa H, Perrier L, Tavares W, et al. Transfer of learning and patient outcome in simulated crisis resource management: a systematic review. Canadian journal of anaesthesia. 2014;61:571-82. https:// doi.org/10.1007/s12630-014-0143-8.

78. Andreatta P, Saxton E, Thompson M, Annich G. Simulation-based mock codes significantly correlate with improved pediatric patient cardiopulmonary arrest survival rates. Pediatric Critical Care Medicine. 2011; 12:33-8. https://doi.org/10.1097/PCC.0b013e3181e89270.

79. Husebø SE. Conditions for learning in simulation practice : training for team-based resuscitation in nursing education. Stavanger: University of Stavanger, Faculty of Social Sciences, Department of Health Studies; 2012.

80. Issenberg SB, McGaghie WC, Petrusa ER, Gordon DL, Scalese RJ. Features and uses of high-fidelity medical simulations that lead to effective learning: a BEME systematic review. Medical Teacher. 2005;27:10-28. https://doi.org/ 10.1080/01421590500046924

81. Cook DA, Brydges R, Hamstra SJ, Zendejas B, Szostek JH, Wang AT, et al. Comparative effectiveness of technology-enhanced simulation versus other instructional methods: a systematic review and metaanalysis. Simulation in Healthcare. 2012;7:308-20. https://doi.org/10.1097/ SIH.0b013e3182614f95.

82. Sollid SJ, Dieckman P, Aase K, Soreide E, Ringsted C, Ostergaard D. Five topics health care simulation can address to improve patient safety: results from a consensus process. J Patient Saf. 2016; https://doi.org/10.1097/pts. 0000000000000254

83. Frenk J, Chen L, Bhutta ZA, Cohen J, Crisp N, Evans T, et al. Health professionals for a new century: transforming education to strengthen health systems in an interdependent world. Lancet. 2010;376:1923-58. https://doi.org/10.1016/S0140-6736(10)61854-5.

84. Husebø SE, Akerjordet K. Quantitative systematic review of multiprofessional teamwork and leadership training to optimize patient outcomes in acute hospital settings. J Adv Nurs. 2016;72:2980-3000. https://doi.org/10.1111/jan.13035.

85. Akram DM, Ismail DF. Simulation training in primary care. InnovAiT. 2016;10: 765-7. https://doi.org/10.1177/1755738016654727.

86. Petrosoniak A, Auerbach M, Wong AH, Hicks CM. In situ simulation in emergency medicine: moving beyond the simulation lab. Emerg Med Australas. 2017;29:83-8. https://doi.org/10.1111/1742-6723.12705.

\section{Ready to submit your research? Choose BMC and benefit from:}

- fast, convenient online submission

- thorough peer review by experienced researchers in your field

- rapid publication on acceptance

- support for research data, including large and complex data types

- gold Open Access which fosters wider collaboration and increased citations

- maximum visibility for your research: over $100 \mathrm{M}$ website views per year

At BMC, research is always in progress.

Learn more biomedcentral.com/submissions 